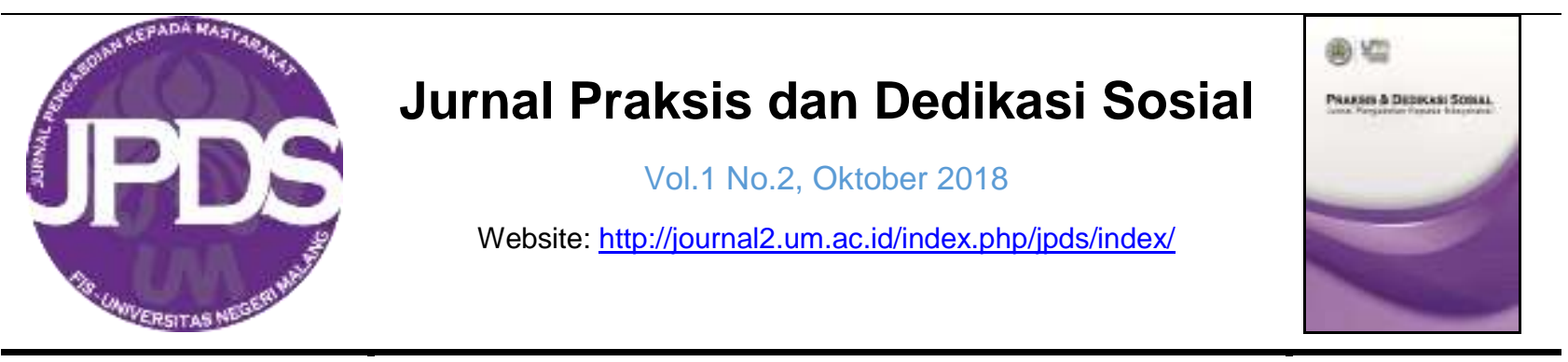

\title{
WORKSHOP PENGEMBANGAN SOAL HIGHER ORDER THINKING SKILL (HOTS) BAGI GURU-GURU MGMP IPS KABUPATEN MALANG PELATIHAN PENYUSUNAN
}

\author{
Neni Wahyuningtyas ${ }^{1}$, Nurul Ratnawati ${ }^{2}$ \\ ${ }^{1,2}$ Prodi Pendidikan IPS, Fakultas IImu Sosial, Universitas Negeri Malang. \\ Diterima 13 Agustus 2018, dipublikasikan 31 Oktober 2018.
}

\begin{abstract}
Abstrak
Beberapa penelitian menunjukkan bahwa kompetensi pedagogik guru pada aspek pengembangan evaluasi hasil belajar masih bersifat konvesional. Maka dari itu, pengabdian di masyarakat yang dilakukan berasaskan pada tujuan meningkatkan kemampuan guru dalam membuat soal yang dapat mendorong siswa untuk memiliki kemampuan menganalisis (C4), mengevaluasi (C5), dan mencipta (C6). Program yang dijalankan yaitu Pelatihan Penyusunan Soal High Order Thinking Skill (HOTS) bagi GuruGuru MGMP IPS Kabupaten Malang. Metode pelaksanaan kegiatan pengabdian ini adalah dengan mengungkap permasalahan yang muncul dikalangan para guru, kemudian dilakukan diskusi pengusul bersama mitra untuk merumuskan akar masalah prioritas yang disepakati, serta menentukan solusi yang tepat. Namun sebelum dilakukan diskusi atau pelatihan, terlebih dahulu pengusul melakukan koordinasi dengan guru-guru MGMP IPS Kabupaten Malang, koordinasi berkaitan dengan kegiatan sosialiasi. Keseluruhan kegiatan pengabdian masyarakat ini dapat dikatakan berhasil, meskipun belum semua peserta pendampingan menguasai cara menyusun soal HOTS.
\end{abstract}

\section{Kata Kunci}

Pengembangan Soal, HOTs, Guru IPS

(C) 2018 Penulis

\section{PENDAHULUAN}

Terkait dengan isu perkembangan pendidikan di tingkat internasional, Kurikulum 2013 dirancang dengan berbagai penyempurnaan. Penyempurnaan antara lain dilakukan pada standar isi yaitu mengurangi materi yang tidak relevan serta pendalaman dan perluasan materi yang relevan bagi peserta didik serta diperkaya dengan

\footnotetext{
${ }^{1}$ Surel Korespondensi: neni.wahyuningtyas.fis@um.ac.id
}

kebutuhan peserta didik untuk berpikir kritis dan analitis sesuai dengan standar internasional. Penyempurnaan lainnya juga dilakukan pada standar penilaian, dengan mengadaptasi secara bertahap model-model penilaian standar internasional. Penilaian hasil belajar diharapkan dapat membantu peserta didik untuk meningkatkan kemampuan berpikir tingkat tinggi (Higher Order Thinking Skills/HOTS), karena berpikir tingkat tinggi dapat mendorong peserta didik 
Workshop Pengembangan Soal Higher Order Thinking Skill...

untuk berpikir secara luas dan mendalam tentang materi pelajaran.

Namun, berdasarkan hasil studi internasional Programme for International Student Assessment (PISA) menunjukkan prestasi literasi membaca (reading literacy), literasi matematika (mathematical literacy), dan literasi sains (scientific literacy) yang dicapai peserta didik Indonesia sangat rendah. Pada umumnya kemampuan peserta didik Indonesia sangat rendah dalam: (1) memahami informasi yang kompleks; (2) teori, analisis, dan pemecahan masalah; (3) pemakaian alat, prosedur dan pemecahan masalah; dan (4) melakukan investigasi (Kemendikbud, 2017).

Data tersebut menunjukkan bahwa siswa Indonesia kesulitan dalam menjawab soalsoal yang berbentuk penalaran. Hal tersebut diperkirakan karena mereka sangat terbiasa dalam mengingat atau menghafal. Pernyataan terebut sejalan dengan pernyataan (Ayuningtyas, 2016) yang menjelaskan bahwa dalam pembelajaran di sekolah guru cenderung menggunakan soal pada buku penunjang yang didominasi dengan indikator mengingat, memahami serta aplikasi dalam Taksonomi Bloom. Soal dengan indikator menganalisis (C4), mengevaluasi (C5), dan mencipta (C6) merupakan soal yang termasuk dalam kriteria HOTS jarang ditemui dalam buku penunjang.

Hal ini menunjukkan bahwa kompetensi pedagogik guru pada aspek pengembangan evaluasi hasil belajar masih bersifat konvesional. Dalam kata lain ketika membuat soal, guru hanya mengambil soal tersebut dari sumber lain, tanpa memperhatikan tujuan pembelajarannya. Akar permasalahan ini antara lain: kurangnya keterampilan pedagogik guru tentang evaluasi hasil belajar; kurangnya pemahaman guru tentang HOTS; dan kemampuan para guru yang belum mumpuni dalam membuat soal HOTS yang dapat mengembangkan daya berpikir kritis siswa.

Kenyataan tersebut di atas juga dialami oleh guru-guru MGMP IPS di Kabupaten Malang, dimana pada waktu pendalaman materi yang diselenggarakan oleh Prodi S1 Pendidikan IPS pada tanggal 7 Februari 2018 diketahui bahwa dari 120 guru yang hadir, sebagian besar belum memahami konsep soal berkriteria HOTS. Dari latihan penyusunan soal-soal, diketahui sebanyak $55,4 \%$ soal yang disusun guru menekankan pada konsep-konsep, 36,3\% pada pengetahuan dan sedikit sisanya menekankan pada aplikasi. Selain itu dari hasil wawancara juga diketahui bahwasanya soal-soal yang selama ini diberikan kepada siswa merupakan soal-soal lama yang hanya dimodifikasi urutan nomor. Bahkan ada juga guru yang hanya copy and paste soal-soal sebelumnya tanpa memodifikasinya. Apabila hal tersebut terus berlanjut, maka akan berdampak juga pada tidak terlatihnya dan berkurangnya kreativitas guru dalam menyusun soal.

Berdasarkan analisis situasi di atas, maka guru diharapkan mampu menyusun soal yang HOTS), yaitu soal-soal yang mampu mengungkap kognitif tingkat tinggi. Oleh sebab itu dalam upaya membantu guru meningkatkan pemahamannya tetang evaluasi hasil belajar dan pembuatan soal 
Neni Wahyuningtyas \& Nurul Ratnawati

HOTS, maka akan dilakukan workshop pengembangan soal Higher Order Thinking Skill (HOTS) bagi guru-guru MGMP IPS Kabupaten Malang.

\section{METODE}

Metode yang diterapkan dalam pengabdian ini adalah dengan mengungkap permasalahan yang muncul dikalangan para guru, kemudian dilakukan diskusi pengusul bersama mitra untuk merumuskan akar masalah prioritas yang disepakati, serta menentukan solusi yang tepat. Namun sebelum dilakukan diskusi atau pelatihan, terlebih dahulu pengusul melakukan koordinasi dengan guru-guru MGMP IPS Kabupaten Malang, koordinasi berkaitan dengan kegiatan sosialiasi, terutama mengenai tempat dan jadwal pelaksanaan, serta perlengkapan dan bahan yang harus dipersiapkan peserta sebelum mengikuti kegiatan pelatihan.

Kegiatan dilaksanakan secara terencana di MTs Negeri 6 Malang dengan tema
Pelatihan Penyusunan Soal High Order Thinking Skill (HOTS) bagi Guru-Guru MGMP IPS Kabupaten Malang pada tanggal 14 Mei 2018 dari pukul 08.30-16.00 WIB Secara garis besar langkah-langkah pelaksanaan tergambar pada Tabel 1.

\section{HASIL DAN PEMBAHASAN}

Pembelajaran dan penilaian hasil belajar merupakan komponen esensial dalam implementasi Kurikulum 2013. Keberhasilan pembelajaran dapat diketahui melalui penilaian. Hasil penilaian juga digunakan untuk menyempurnakan pembelajaran. Keterpaduan dan kefektifan pembelajaran dan penilaian sangat besar perannya dalam keberhasilan implementasi Kurikulum 2013.

Hasil monitoring dan evaluasi pelaksanaan Kurikulum 2013 tingkat SMP pada tahun 2014 menunjukkan bahwa salah satu kesulitan pendidik dalam mengimplementasikan Kurikulum 2013 adalah dalam melaksanakan penilaian hasil belajar. Sekitar $60 \%$ responden pendidik

\begin{tabular}{|c|c|}
\hline Permasalahan & Metode Pelaksanaan Kegiatan \\
\hline $\begin{array}{l}\text { Kurangnya pengetahuan dan } \\
\text { pemahaman guru IPS tentang } \\
\text { konsep penyusunan soal Higher } \\
\text { Order Thinking Skills }\end{array}$ & $\begin{array}{l}\text { 1. Memberikan wawasan pengetahuan tentang konsep } \\
\text { penyusunan soal Higher Order Thinking Skills } \\
\text { 2. Memberikan wawasan pengetahuan tentang bagaimana } \\
\text { penyusunan tes evaluasi hasil belajar yang benar sesuai } \\
\text { dengan KD, indikator, dan tujuan pembelajaran }\end{array}$ \\
\hline $\begin{array}{l}\text { Kurangnya keterampilan guru-guru } \\
\text { IPS dalam menyusun soal-soal } \\
\text { Higher Order Thinking Skills yang } \\
\text { dapat mengembangkan daya } \\
\text { berpikir kritis siswa }\end{array}$ & $\begin{array}{l}\text { 1. Memberikan pelatihan dalam menyusun soal-soal Higher Order } \\
\text { Thinking Skills yang disajikan dalam bentuk kisi-kisi } \\
\text { penyusunan soal dengan langkah sebagai berikut: } \\
\text { a. Mengkaji KI dan KD } \\
\text { b. Mengembangkan KI dan KD menjadi indikator soal } \\
\text { c. Penulisan soal oleh guru sesuai dengan indikator soal } \\
\text { d. Telaah soal secara kualitatif berdasarkan kaidah penulisan } \\
\text { butir soal } \\
\text { e. Perakitan soal } \\
\text { f. Presentasi dan pemberian umpan balik }\end{array}$ \\
\hline
\end{tabular}

Tabel 1. Langkah-Langkah Pelaksanaan Kegiatan 
Workshop Pengembangan Soal Higher Order Thinking Skill...

menyatakan bahwa mereka belum dapat merancang, mengembangkan instrumen, melaksanakan, mengolah, melaporkan, dan memanfaatkan hasil penilaian dengan baik. Kesulitan utama yang dihadapi pendidik meliputi merumuskan indikator, menyusun dan mengembangkan butir-butir soal pengetahuan. Mereka kurang memahami bagaimana merumuskan indikator dan menyusun butir-butir soal untuk pengetahuan faktual, konseptual, dan prosedural yang dikombinasikan dengan keterampilan berpikir tingkat rendah hingga tinggi.

Berkaitan dengan kesulitan pendidik tersebut, tim dosen Prodi S1 Pendidikan IPS FIS UM melakukan kegiatan pengabdian kepada masyarakat dengan tema Pelatihan Penyusunan Soal High Order Thinking Skill (HOTS) bagi Guru-Guru MGMP IPS Kabupaten Malang. Diselenggarakan pada tanggal 14 Mei 2018 dari pukul 08.30-16.00 WIB. Tujuan dari kegiatan ini adalah untuk menambah wawasan dan pemahaman dalam penyusunan soal HOTS. Soal HOTS adalah instrumen pengukuran yang digunakan untuk mengukur kemampuan berpikir tingkat tinggi, yaitu kemampuan berpikir yang tidak sekedar mengingat (recall), menyatakan kembali (restate) atau merujuk tanpa melakukan pengolahan (recite). Pengetahuan mengenai soal HOTS penting diketahui oleh guru-guru dalam melaksanakan pembelajaran menggunakan kurikulum 2013, karena salah satu penyempurnaan pada kurikulum 2013 yaitu mengenai standar penilaian yang memberikan ruang pada pengembangan instrumen penilaian yang mengukur berpikir tingkat tinggi. Guru-guru diharapkan mampu menyusun soal-soal HOTS agar siswa memiliki kemampuan dalam menjawab pertanyaan dengan tingkat kesulitan C-4 (sintesis/analisis), C-5 (evaluasi), dan C-6 (berkreasi).

Kegiatan pengabdian masyarakat ini dihadiri 25 orang guru IPS MTs yang berasal dari Kabupaten Malang. Adapun produk yang dihasilkan dalam kegiatan ini adalah soalsoal beserta kisi-kisinya. Metode kegiatan pengabdian yang diterapkan oleh tim dosen yaitu in-service berupa pelatihan dan pendampingan. Sesi pertama pada kegiatan pengabdian yaitu pemateri memberikan wawasan pengetahuan tentang konsep penyusunan soal Higher Order Thinking Skills. Kemudian dilanjutkan dengan memberikan wawasan pengetahuan tentang bagaimana penyusunan tes evaluasi hasil belajar yang benar sesuai dengan $K D$, indikator, dan tujuan pembelajaran, serta diakhir sesi melatih dan mendampingi guruguru dalam menyusun soal-soal HOTs yang disajikan dalam bentuk kisi-kisi penyusunan soal.

Pada awal kegiatan diadakan sesi curah pendapat yang disampaikan guru-guru. Pemateri juga melakukan penjajakan kemampuan awal peserta terkait konsep penyusunan soal HOTS. Hasilnya diketahui bahwasanya guru seringkali menyepelekan dalam pembuatan soal penilaian harian yang sebenarnya sangat berpengaruh untuk mengukur tingkat pencapaian siswa dan keberhasilan guru dalam menyampaikan materi pelajaran. Beberapa guru juga menyatakan bahwa mereka tidak pernah mengikuti pelatihan atau workshop tentang 
pembuatan soal HOTS. Tidak mengherankan ketika pemateri menjelaskan tentang konsep HOTS, peserta sangat antusias dan bersemangat mencatat semua hal yang disampaiakn pemateri. Pada kesempatan tersebut salah satu peserta pelatihan menanyakan taksonomi itu apa? dan apakah ada perbedaan KKO dari Taksonomi Bloom tersebut untuk aspek pengetahuan dan psikomotor? Berdasarkan pertanyaan yang dilontarkan oleh peserta tersebut, pemateri menjelaskan jika konsep taksonomi adalah kriteria yang digunakan oleh guru untuk mengevaluasi mutu dan efektivitas pembelajarannya. Dalam setiap aspek taksonomi terkandung kata kerja operasional yang menggambarkan bentuk perilaku yang ingin dicapai melalui suatu pembelajaran. Kata kerja operasional ini diperlukan oleh guru saat menyusun silabus dan RPP. Masing-masing domain yaitu kognitif, afektif dan psikomotor memiliki rumusan kata kerja operasional yang berbeda-beda. Kata kerja operasional dari taksonomi Bloom untuk domain psikomotor (ketrampilan) meliputi: (1) $\mathrm{P} 1 \rightarrow \quad$ Menirukan: mengaktifkan, menyesuaikan, dll; (2) P2 $\rightarrow$ Memanipulasi: mengoreksi, mendemonstrasikan, merancang dll; (3) P3 $\rightarrow$ Pengalamiahan: mengalihkan, mendorong dsb; (4) $\mathrm{P} 4 \rightarrow$ Artikulasi: mempertajam, membentuk, menimbang dsb.

Pertanyaan berikutnya disampaikan oleh peserta lainnya yaitu "Stimulus dalam konsep soal HOTS itu yang seperti apa?" Pemateri menjelaskan jika stimulus dalam penyusunan soal-soal HOTS merupakan dasar untuk membuat pertanyaan. Dalam konteks HOTS, stimulus yang disajikan hendaknya bersifat kontekstual dan menarik. Stimulus dapat bersumber dari isu-isu global yang ada di lingkungan sekitar satuan pendidikan seperti budaya, adat, kasus-kasus di daerah atau berbagai keunggulan yang terdapat di daerah tertentu. Kreativitas seorang guru sangat mempengaruhi kualitas dan variasi stimulus yang digunakan dalam penyusunan soal HOTS.

Pada saat praktik penyusunan soal, beberapa peserta belum bisa menyelesaikan keseluruhan soal yang ditugaskan. Hal ini dikarenakan ada dari mereka yang memang sudah membawa bahan soal dan ada yang belum. Padahal sebelum kegiatan ini dilaksanakan, persyaratan wajib peserta sebelum mengikuti kegiatan pelatihan adalah membawa soal-soal yang telah mereka susun di rumah. Bagi peserta yang sudah membawa, mereka dapat menyelesaikan soal-soalnya sampai akhir dan mendapatkan review dari pemateri. Bagi yang belum selesai, pemateri memberi kesempatan kepada peserta tersebut untuk melanjutkan atau menyelesaikan soal yang disusun di rumah, dengan catatan soal-soal yang sudah selesai harus dikirimkan kembali melalui email untuk memperoleh umpan balik.

Saat pemateri mereview soal yang telah dibuat oleh peserta, muncul pertanyaan dari bapak Alex yaitu mengapa dalam proses penyusunan soal HOTS, kita harus menggunakan bentuk soal yang beragam? 
Workshop Pengembangan Soal Higher Order Thinking Skill...

Pada kesempatan tersebut pemateri menjelaskan jika bentuk soal yang beragam dalam perangkat tes soal-soal HOTS sebagaimana yang digunakan dalam PISA, bertujuan agar dapat memberikan informasi yang lebih rinci dan menyeluruh tentang kemampuan siswa yang mengikuti tes. Hal ini penting diperhatikan oleh guru agar penilaian yang dilakukan dapat menjamin prinsip obyektif. Artinya, hasil penilaian yang dilakukan oleh guru dapat menggambarkan kemampuan siswa sesuai dengan keadaan yang sesungguhnya.

Beberapa faktor yang mendukung terlaksananya kegiatan pengabdian masyarakat ini adalah besarnya minat dan antusiasme peserta selama kegiatan, sehingga kegiatan berlangsung dengan lancar dan efektif. Sedangkan faktor penghambatnya adalah: 1) terbatasnya kemampuan guru dalam mengenal tingkatan taksonomi Bloom yang ke arah HOTS, 2) keterbatasan waktu pelatihan, dan 3) ada beberapa peserta yang tidak membawa bahan soal.

Di akhir kegiatan, peserta memberikan masukan dan saran terkait dengan pelaksanaan pengabdian ini. Masukan dan saran peserta antara lain adalah: 1) terkait kuota peserta, yang diharapkan dapat bisa ditingkatkan; 2) kegiatan seperti pelatihan penyusunan soal ini kalau bisa dilakukan secara rutin, mengingat setiap bulan ada jadwal MGMP, sehingga bisa mengisi kegiatan MGMP; 3) mengingat besarnya manfaat kegiatan pengabdian pada masyarakat ini, maka saran peserta untuk tahun-tahun berikutnya atau pengabdian berikutnya mengharapkan adanya kegiatan seperti pelatihan kembali dengan tema yang berbeda misalnya workshop tentang pembuatan modul, media dan model-model pembelajaran, 4) diharapkan kegiatan pelatihan-pelatihan bisa merata menjangkau seluruh wilayah Malang Raya.

\section{KESIMPULAN}

Keseluruhan kegiatan pengabdian masyarakat dengan tema "Pelatihan Penyusunan Soal High Order Thinking Skill (HOTS) bagi Guru-Guru MGMP IPS Kabupaten Malang" dapat dikatakan berhasil, meskipun belum semua peserta pendampingan menguasai cara menyusun soal HOTS. Kegiatan ini mendapat sambutan baik terbukti dengan keaktifan peserta mengikuti pelatihan dengan tidak meninggalkan tempat sebelum pelatihan berakhir. Selain itu keberhasilan dapat diukur dari banyaknya guru-guru yang telah mengumpulkan produk soal HOTS sebagai hasil pelatihannya.

\section{DAFTAR PUSTAKA}

Anderson, Lorin W. Dan David R. Krathwohl (Ed). 2001. Kerangka Landasan untuk Pembelajaran Pengajaran dan Asesmen, Revisi Taksonomi Pendidikan Bloom. Yogyakarta: Pustaka Pelajar.

Ayuningtyas, Nurina, dkk. 2016. Proses Penyelesaian Soal Higher Order Thinking Materi Aljabar Siswa SMP Ditinjau Berdasarkan Kemampuan Matematika Siswa, (Online), diakses tanggal 26 Februari 2018.

Kemendikbud. 2017. Modul Penyusunan Soal HOTS. Jakarta: Direktorat Pembinaan SMA Ditjen Pendidikan Dasar dan Menengah.

Permendikbud Nomor 53 Tahun 2015 tentang Penilaian Hasil Belajar oleh Pendidik dan Satuan Pendidikan. 
Permendikbud Nomor 23 Tahun 2016 tentang Standar Penilaian Pendidik.

Permendikbud Nomor 24 Tahun 2016 tentang Kompetensi Inti dan Kompetensi Dasar Pelajaran pada Kurikulum 2013.
Rochmadi, N.W. 2018. Pengembangan Soal HOTS. Makalah disajikan dalam kegiatan Pelatihan Kompetensi Tenaga Pendidik Jenjang SMP/MTs di MTs Kota Malang. 